RESEARCH PAPER

J. Food Sci. Technol. Nepal, Vol. 8 (40- 45) 2013

ISSN: 1816-0727

\title{
Formulation and Quality Evaluation of Extruded Product From Composite Blend of Maize, Sorghum and Ricebean
}

\author{
BANDANA LAMICHHANE*, PRAVIN OJHA and BHUPENDRA PAUDYAL
}

National College of Food Science and Technology, Khusibu, Kathmandu

*Corresponding author: bandanalamichhane7@gmail.com

This research work was based on formulation of cereal based extruded product utilizing the underutilized grains of Nepal i.e. sorghum (white variety) and ricebean (yellow variety). The formulation having $76 \%$ maize, $15 \%$ sorghum and $9 \%$ ricebean was found best through sensory analysis. While further variation in grit particle size ranging from $550 \mu \mathrm{m}$ to $1190 \mu \mathrm{m}$, the product formulated with average particle size of $1090 \mu \mathrm{m}$ was found to have best. The optimum grit size was selected by sensory analysis, chemical analysis and physico-chemical analysis. The expansion value for product of $1090 \mu \mathrm{m}$ grit size was maximum $3.88 \pm 0.36$, and minimum value $3.02 \pm 0.14$ for smaller particle size 550 $\mu \mathrm{m}$. The density was minimum, $80.46 \pm 12.72 \mathrm{~kg} / \mathrm{m}^{3}$ for product of $1090 \mu \mathrm{m}$ grit size and maximum, $175.33 \pm 11.89 \mathrm{~kg} /$ $m^{3}$ for product of $550 \mu \mathrm{m}$ grit size. The soluble fiber, $\beta$-glucan, WAI (water absorption index) and WSI (water soluble index) were found to be $6.52 \pm 0.61 \%(d b), 9.77 \pm 0.52$ and $21.48 \pm 0.82$ respectively for final product of grit size 1090 $\mu \mathrm{m}$.

Keywords: extruded product, underutilized grain, expansion and density, WAI and WSI, $\beta$-glucan

\section{Introduction}

Extrusion cooking is a high-temperature, short-time process in which moistened, starchy and/or protenacious food materials are plasticized and cooked in a tube by a combination of moisture, pressure, temperature and mechanical shear, resulting in molecular transformation and chemical reactions (Castells et al., 2005). When such extruded products are made exclusively from corn ingredient, they often lack in macro-nutrients like proteins. Considerable interest has been paid in fortifying cereals with high protein, high lysine material to increase the protein content and improve the essential amino acid balance of extruded products (Obatolu \& Cole, 2000). Also, there is a growing interest in increasing the dietary fiber content of foods including extruded snacks from nutrition and health standpoint.

In Nepal, Ricebean is grown in uncultivated marginal land contributing food and nutritional security. Being a native species of legume and high local adaptability it can be grown well in the less fertile, exhausted, degraded marginal land without much effort and input. Therefore present situation of the ricebean is not good in terms of production, coverage and utilization despite its great potentiality (Acharya, 2008). Sorghum is similar to maize in its nutritional property. Sorghum food products occupy a low position in a diet due to poor grain quality attributes. The dark color, high fiber content, pronounced flavor, grittiness of flour and difficulty to cook into the soft products like bread, biscuit, cake and pastries, are some of the disadvantages. (Udachan et al., 2012).One way of utilization of sorghum for commercial purpose is by blending with other grains flour as in the form of composite flour.

The digestibility of legume protein and legume starch is limited by the presence of anti-nutrients However, extrusion has been reported to cause the biggest effect in reduction of anti-nutritional factors and has appeared to be very effective in improving both in vitro protein digestibility and in vitro starch digestibility of legumes (Alonso, 2000).

Average particle size affects on water absorption and solubility and nutritional property (e.g. starch digestion) (Al-Rabadi et al., 2012).

$\beta$-D-Glucan is a major cell wall carbohydrate, found usually in cereals like oats, barley, rye etc. It acts as dietary fiber with important dietary properties (AACI, 2001) with cholesterol lowering properties and stabilization of serum glucose level in human (Sikora et al., 2013) and have the ability to stimulate anti-tumor and antimicrobial properties (Brown \& Gordon, 2001).

\section{Materials and Methods \\ Acquisition of samples}

The raw materials sorghum, ricebean and maize were collected from Ason, the local market of Kathmandu. The variety of sorghum chosen was white sorghum (Sorghum bicolor moench) and ricebean was yellow variety (Vigna umbellata.) very commonly found in our 
Nepalese market. The grains were then sorted, cleaned and then sun dried prior to milling.

Milling and Preparation of grit Dried grains were then milled in a Hammer Mill. Grits were separated from husk and flour by winnowing and sieving method. Using seven different mesh (Standard Indian mesh) grits were obtained by sieving. Grits of maize, sorghum and ricebean were segregated into 5 different particle sized group. Grit of different particle size can be obtained by segregation by sieving (Carvalho et al., 2010).

Optimization of formulation by sensory evaluation From the preliminary study on raw material proportion of extruded cereal based snack done at Marigold Pvt Ltd, Gondrang, Chitwan, four different formulations were selected with different proportion of maize, sorghum and ricebean keeping moisture content of final mix (17\%), screw speed (153 rpm) and extrusion temperature $\left(135^{\circ} \mathrm{C}\right)$ fixed and same for all four formulations:

$75 \%$ maize, $17 \%$ sorghum, $8 \%$ ricebean-sample A,

$76 \%$ maize, $15 \%$ sorghum, $9 \%$ ricebean-sample B,

$70 \%$ maize, $15 \%$ sorghum, $15 \%$ ricebean- sample $\mathrm{C}$ and

$75 \%$ maize, $10 \%$ sorghum, $15 \%$ ricebean- sample $\mathrm{D}$, a formulation was selected on the basis of sensory analysis of product on that proportion grit size was varied.

Product development by extrusion and optimization of grit particle size Keeping different parameters like moisture content of grit mix (17\%), speed of rotor of extruder (153 rpm), extrusion temperature $\left(135^{\circ} \mathrm{C}\right)$, dryer (roller drum dryer) and drying temperature $\left(135^{\circ} \mathrm{C}, 10 \mathrm{~min}\right)$ fixed, effect of grit size on final product was analyzed on the basis of chemical composition, physico-chemical parameters and sensory analysis.

Table 1. Description of five different size of grit prepared

\begin{tabular}{cc}
\hline Product & Average particle \\
\hline D1 & 1290 \\
D2 & $(\mu \mathrm{m})$ \\
D3 & 1090 \\
D4 & 925 \\
D5 & 725 \\
\hline
\end{tabular}

Chemical

analysis

Moisture, Protein and Carbohydrate was determined according to AOAC (2005). Fat and Ash contents was estimated as per Rangana (2000).
Physico-chemical analysis

Density, expansion, Water absorption index (WAI) and Water solubility index (WSI) Extrudate density was estimated as Martinez et al. (1988). The ratio of diameter of extrudate and diameter of die was used to express the expansion of extrudate as Martinez et al., 1988. The WAI and WSI were measured using a technique developed for cereals (Anderson et al., 1969).

\section{Sensory analysis}

Sensory analysis of product was performed by $y$ point hedonic scoring test $(9=$ extremely like, $1=$ extremely dislike) carried out by 15 semi-trained panelist comprising of graduate student, teachers of NCFST and professionals from Department of Food Technology and Quality Control (DFTQC). Each panelist was provided with 4 coded sample (for proportion optimization) and 5 coded sample (for grit size optimization) with random numbers in an evaluation card to score for parameters like appearance, color, texture, taste and overall acceptance (for proportion optimization) and to score for appearance, texture, taste, expansion, and overall acceptance (for grit size optimization).

\section{$\beta$-Glucan content}

The amount of $\beta$-glucan was determined according to Rhee et al. (2007) by alkali extraction method.

\section{Statistical analysis}

Data were statistically processed by GenStat Discovery Edition 4, GenStat for Analysis of Variance (ANOVA), means of data were separated whether they are significantly different or not by using LSD ( least square difference) method at 5\% level of significance.

\section{Results and Discussion}

Sensory evaluation of preliminary trial product Sensory evaluation of preliminary trial products were carried out to find the best proportion of grits for product formulation. The results of analysis are presented in table 2.

Statistical analysis showed that there was no significant difference in appearance between the samples at 5\% level of significance. Sample C with lowest appearance attribute can be correlated with comparative higher substitution of maize with ricebean and sorghum. 
Lamichhane et al.: J. Food Sci. Technol. Nepal, Vol. 8 (40-45 ), 2013

Table 2. Result of sensory analysis of preliminary trial product

\begin{tabular}{lllllc}
\hline Product code & Appearance & Color & Taste & Texture & Overall acceptance \\
\hline A & $7 \pm 0.5^{\mathrm{ab}}$ & $6.3 \pm 0.72^{\mathrm{a}}$ & $7.3 \pm 0.67^{\mathrm{a}}$ & $6.9 \pm 0.5^{\mathrm{a}}$ & $7 \pm 0.47^{\mathrm{a}}$ \\
$\mathrm{B}$ & $6.78 \pm 0.67^{\mathrm{ab}}$ & $6.2 \pm 0.83^{\mathrm{a}}$ & $6.8 \pm 0.9^{\mathrm{a}}$ & $6.9 \pm 0.56^{\mathrm{a}}$ & $6.6 \pm 0.96^{\mathrm{ab}}$ \\
$\mathrm{C}$ & $6.33 \pm 0.70^{\mathrm{a}}$ & $6 \pm 1.1^{\mathrm{a}}$ & $6.7 \pm 0.67^{\mathrm{a}}$ & $6 \pm 1.4^{\mathrm{b}}$ & $6.2 \pm 1.13^{\mathrm{b}}$ \\
$\mathrm{D}$ & $7.3 \pm 1^{\mathrm{b}}$ & $7.2 \pm 1.09^{\mathrm{ab}}$ & $7 \pm 0.47^{\mathrm{a}}$ & $7 \pm 0.47^{\mathrm{a}}$ & $7.2 \pm 0.78^{\mathrm{a}}$ \\
\hline
\end{tabular}

Mean \pm S.D, score having different subscript letters are significantly different $(\mathrm{p}<0.05)$

The color attribute of sample D was significantly higher. Presence of pericarp (due to improper milling) in extrusion may give darker color (Mariotti et al., 2006). The non enzymatic browning reactions (Maillard reaction, caramelisation) also affect the colour. Low moisture content and high barrel temperature favors the millard browning (Ilo and Berghofer, 1999). Statistical analysis showed that there was no significant difference in taste attribute in different samples $(\mathrm{p}<0.05)$.

Statistical analysis showed that there was significant difference in taste attribute among samples. The lower texture value of sample $\mathrm{C}$ might be due to higher substitution of maize starch. Higher amount of feed moisture and proteinaceous substance increases the The chemical composition of product having different grit size are shown in Table 3 .

Table 3. Chemical compositions of product with different grit size

\begin{tabular}{llllll}
\hline & \multicolumn{5}{c}{ Formulations } \\
\cline { 2 - 6 } Parameters & D1 & D2 & D3 & D4 & D5 \\
\hline Moisture (\%) & $0.71 \pm 0.08^{\mathrm{a}}$ & $0.676 \pm 0.05^{\mathrm{a}}$ & $0.69 \pm 0.02^{\mathrm{a}}$ & $0.86 \pm 0.014^{\mathrm{b}}$ & $0.85 \pm 0.03^{\mathrm{b}}$ \\
Crude protein (\%) & $2.45 \pm 0.44^{\mathrm{a}}$ & $2.97 \pm 0.16^{\mathrm{a}}$ & $2.40 \pm 0.08^{\mathrm{a}}$ & $2.69 \pm 0.13^{\mathrm{a}}$ & $2.31 \pm 0.09^{\mathrm{a}}$ \\
Crude fat (\%) & $1.07 \pm 0.15^{\mathrm{a}}$ & $1.87 \pm 0.56^{\mathrm{ab}}$ & $1.75 \pm 0.79^{\mathrm{ab}}$ & $2.21 \pm 0.39^{\mathrm{b}}$ & $2.46 \pm 0.43^{\mathrm{b}}$ \\
Crude fiber (\%) & $12.35 \pm 0.41^{\mathrm{a}}$ & $12.06 \pm 0.37^{\mathrm{a}}$ & $11.78 \pm 0.31^{\mathrm{ab}}$ & $12.371 \pm 0.31^{\mathrm{a}}$ & $11.2 \pm 0.40^{\mathrm{b}}$ \\
Ash (\%) & $2.14 \pm 0.07^{\mathrm{a}}$ & $2.54 \pm 0.184^{\mathrm{b}}$ & $2.60 \pm 0.10^{\mathrm{b}}$ & $2.34 \pm 0.17^{\mathrm{ab}}$ & $2.58 \pm 0.31^{\mathrm{b}}$ \\
Carbohydrate (\%) & $81.26 \pm 0.72^{\mathrm{a}}$ & $79.86 \pm 0.7^{\mathrm{a}}$ & $80.76 \pm 1.1^{\mathrm{a}}$ & $79.48 \pm 1.06^{\mathrm{b}}$ & $80.83 \pm 0.83^{\mathrm{a}}$ \\
\hline
\end{tabular}

Mean \pm S.D $(\%, d b)$, carbohydrate $(\%, d b)$ estimated by difference, means having different subscription are significantly different ( $<<0.05)$. There is significant increase in moisture content as grit particle size decreases. This can be related with the fact that as the size increases there is considerable increase in expansion and drying eases with highly expanded product.

The fat content of formulation D5 was obtained to be highest with value $2.46 \pm 0.43$, while fat content was obtained to be $1.07 \pm 0.15,1.87 \pm 0.56,1.75 \pm 0.79$ and $2.21 \pm 0.39$ for formulation D1, D2, D3 and D4 respectively. The gradual increase in fat content can related with the fact that smaller sized grit contains rigidity and stiffness in product. (Anton et al., 2009). There was significant difference in overall acceptance of samples $(\mathrm{p}<0.05)$. Sample D has higher overall acceptability and sample $\mathrm{C}$ with higher substitution of maize has lower overall acceptability. With decreasing the sorghum content and consequent increasing the amount of ricebean has correspondingly increased in overall acceptability of product.

\section{Effect of grit size on chemical composition of final extruded products}

Based upon the preliminary study on sensory quality formulation D was found to be the best product. Using the proportion of ingredient as in formulation $\mathrm{D}$, further products were developed varying their grit size. Five different group of grit size were prepared for the study. considerable amount of germ after milling from maize, sorghum and ricebean.

Fibers of products were significantly different $(p<0.05)$. The Codex Alimentarius recommends that to claim a food is "high" in fiber, the product must contain at least 6 $\mathrm{g}$ of fiber per $100 \mathrm{~g}$ of serving or $3 \mathrm{~g}$ of fiber per $100 \mathrm{kcal}$ of serving or $20 \%$ of daily reference value per serving (Codex, 2009a) (Frederic R, 2012).

Similarly protein content for formulation D2 was obtained to be highest and formulation D5 has lowest protein value. 


\section{Effect of variation on grit size on sensory quality of the} final extruded product

Sensory evaluation was based on four sensory parameters viz. color of the product, appearance, taste, texture and overall acceptance of the product and is presented in figure 1. Formulation D2 has the best average appearance score, 7.6 \pm 0.751 . However with increase in grit particle size appearance score has been gradually increased. The average appearance score for formulation D1, D3, D4 and D5 was obtained to be $7.3 \pm 0.75,7.30 \pm 0.94,5.84 \pm 1.21$ and $5.23 \pm 1.09$ respectively.

Taste score for formulation D1, D2, D3, D4 and D5 was obtained to be $6.84 \pm 0.55,7 \pm 1.15,7 \pm 0.81,6.15 \pm 1.34$ and $6.07 \pm 1.11$ respectively. Formulation sample D2 has the highest taste score and D5 has the lowest taste score. There was no significant difference between taste score of formulation D1, D2 and D3 at 5\% level of significance. Taste score decreases with decrease in particle grit size. Average texture score for formulation D1, D2, D3, D4 and D5 were obtained to be $6.61 \pm 1.19,7.46 \pm 1.12$, $6.84 \pm 1.06,5.46 \pm 1.05$ and $5.46 \pm 1.76$ respectively.

Average overall acceptance score for formulation sample D1, D2, D3, D4 and D5 were obtained to be $7 \pm 0.57,7.92 \pm 0.95,7.07 \pm 0.64,5.92 \pm 1.03$ and $5.69 \pm 1.10$ respectively. Formulation sample D1 has the highest overall acceptance value and D5 has the lowest overall acceptance score .Expansion value for product D4 and D5 were significantly different with product D1, D2 and D3 $(\mathrm{p}<0.05)$.

Average expansion score for formulation D1, D2, D3, D4 and D5 were obtained to be $7.15 \pm 0.68,7.84 \pm 0.68$, $7.30 \pm 0.75, \quad 5.53 \pm 1.05$ and $5.38 \pm 1.19$ respectively. Expansion of formulation D1, D2, D3 were significantly higher as compared to formulation D4 and D5 ( $<<0.05)$. This value can be related with corresponding starch content. Extrudates produced from higher particle size expanded more than those from smaller particle sizes.

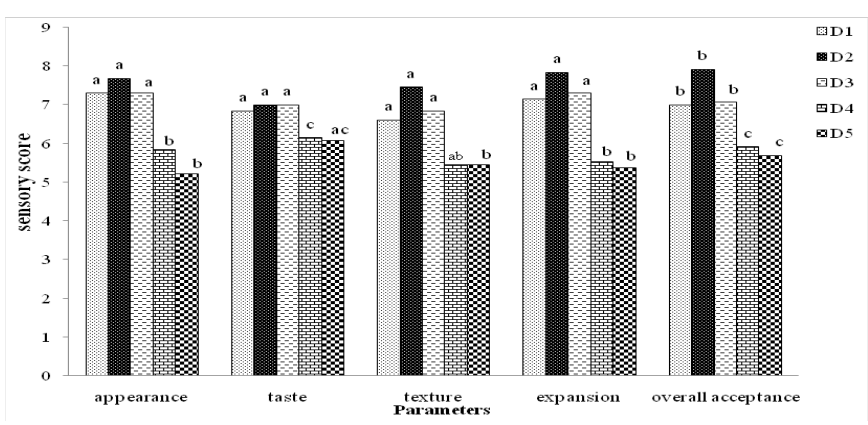

Figure 1. Summary of sensory analysis Score having different subscript letters are significantly different $(\mathbf{p}<0.05)$
Effect of grit size on physiochemical parameters of final extruded product

\section{Effect of grit size on density of final product}

Extrudate density is highly correlated with the moisture content (Onwulata et al., 1994). It increases with moisture content, feed rate and decreases with temperature. The density values of formulation are significantly differet $(p<0.05)$. Average density score for formulation sample D1, D2, D3, D4 and D5 were obtained to be 146.86 $\pm 8.8,80.46 \pm 12.72,91.20 \pm 12.23,158.97 \pm 14.06$ and $175.33 \pm 11.89$ respectively. Product with smallest grit size, D5 has the highest density and sample D2 has the lowest density value. Excluding formulation sample $\mathrm{D} 2$, there is gradual increase in density with decrease in grit particle size. Bulk density of extrudate is inversely proportional to volumetric expansion (Altan et al., 2009).

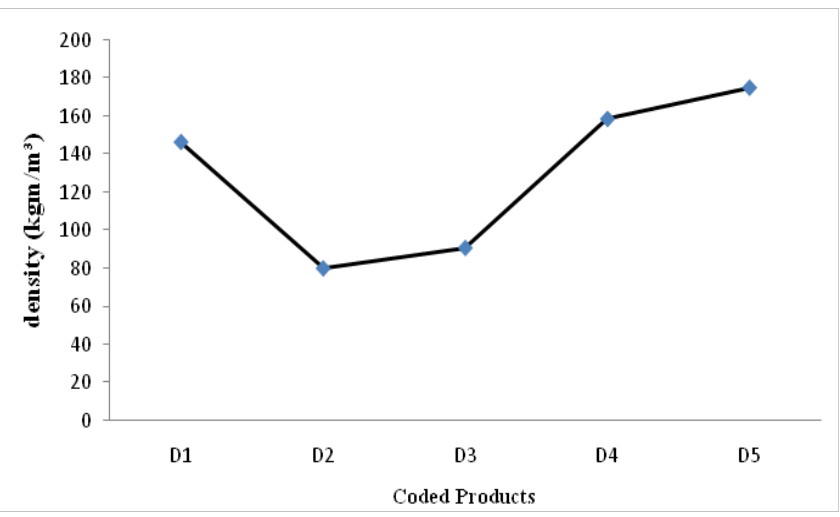

Figure 2. Density of respective formulated samples.

\section{Effect of grit size on expansion}

Expansion increased with increase in particle size and decreased with increase in feed moisture content. Expansion of formulated product was significantly different $(p<0.05)$. Average expansion of formulated product samples D1, D2, D3, D4 and D5 with reference to $4 \mathrm{~mm}$ die opening were obtained to be $3.20 \pm 0.09$, $3.88 \pm 0.36, \quad 3.87 \pm 0.17, \quad 3.16 \pm 0.14$ and $3.02 \pm 0.14$ respectively. The variation in expansion might be a result of difference in moisture content.

The higher expansion was obtained to be $3.88 \pm 0.36$ for formulation sample D2, which has corresponding lowest density value among the five different samples. Soluble fiber like beta glucan acts as a barrier in starch swelling (Al-Rabadi et al., 2011) and ultimate expansion of product.

From all the chemical analysis, sensory analysis and physiochemical analysis sample D2 was obtained to be the best formulation among all five formulations made varying the grit particle size. Further analysis of sample D2 was done to find the functional property of the product. 
Lamichhane et al.: J. Food Sci. Technol. Nepal, Vol. 8 (40-45 ), 2013

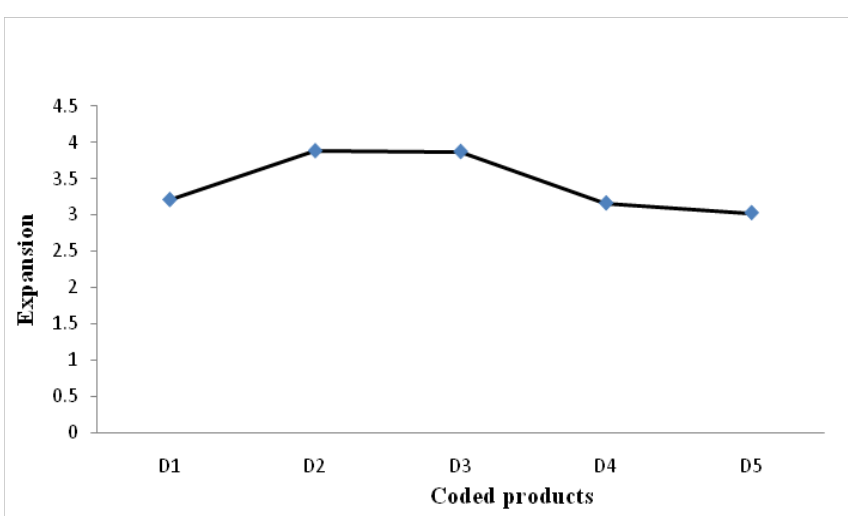

Figure 3. Expansion of product samples

Functional property evaluation of the final best product Beta glucan content, WSI and WAI in the final product Beta glucan content in the final selected product was obtained to be $6.52 \pm 0.61$. Similarly water soluble index (WSI) and water absorption index (WAI) were obtained to be $21.48 \pm 0.82$ and $9.77 \pm 0.52$ respectively. WSI decreases with the increase in feed moisture and increased with the increase in extrusion temperature and screw speed. Increasing corn meal particle size decreased WAI values (Carvalho et al., 2010).

\section{Conclusions}

Among all trial formulations, formulation having $76 \%$ maize, $15 \%$ sorghum, and $9 \%$ ricebean was found to be best through sensory analysis and cost evaluation. Moisture content and fat content of extruded product thus made was found to be increased with decrease in grit size. There were no significant correlation between grit size and other parameter like protein, fibre content and carbohydrate. Extruded product prepared from grit size of $1190 \mu \mathrm{m}$ was found to be best on the basis of sensory evaluation. Density of extruded product was found to be decreased with increase in grit size. The higher expansion was obtained to be $3.88 \pm 0.36$ for formulation sample having grit size $1190 \mu \mathrm{m}$. Beta glucan content in the final selected product was obtained to be $6.52 \pm 0.61$. Similarly water soluble index (WSI) and water absorption index (WAI) were obtained to be $21.48 \pm 0.82$ and $9.77 \pm 0.52$ respectively.

\section{References}

AOAC (2005). Official Methods of Analysis, 18th edition, Association of Official Analytical Chemist, Washington D.C.

Acharya B.K., (2008). Cultivation and Use of Ricebean A Case Study of Dang District, Nepal. Department of Geography University of Bergen., Norway.

Alonso R., Aguirre A., Marzo F., (2000). Effects of extrusion and traditional processing methods on antinutrients and in vitro digestibility of protein and starch in faba and kidney beans. Food Chemistry, 68, 159-165.

Al-Rabadi G.J., Torley P.J., Williams B.A., Bryden W.L., Gidley M.J. (2011). Particle size of milled barley and sorghum and physico-chemical properties of grain following extrusion. Journal of Food Engineering, 103, 464-472.

Al-Rabadi G.J., Torley P.J., Williams B.A., Bryden W.L., Gidley M.J. (2012). "In Press" Particle size heterogeneity in milled barley and sorghum grains: Effects on physico-chemical properties and starch digestibility, Journal of Cereal Science, 1-8.

(AACCI) American Association of Cereal Chemists International (2001). "The defination of dietary fiber." Cereal Food World. 46:11

Anton A., McCarthy K.L., Maskan M., (2009). Effect of screw configuration and raw material on some properties of barley extrudates. Journal of Food Engineering 92 (4): 377-382.

Anderson R. A., Conway, H. F. M., Pfeiffer, V. F., \& Griffin, E. J. (1969). Gelatinization of corn grits by roll and extrusion cooking. Cereal Science Today, 14: 4-12.

Altan A.A., Ross K.A., Beta T., Fulcher R.G., Arntfield S.D., (2009). Effect of pre-dehulling treatments on some nutritional and physical properties of navy and pinto beans (Phaseolus vulgaris L.). Lebensm.

-Wiss. Technol. 41:771-778.

Brown G. D., \& Gordon S. (2001). A new receptor for $\beta$-glucans. Nature, 413: 36-37.

Castells M., Marin S., Sanchis V. \& Ramos A.J. (2005). Fate of mycotoxins in cereals during extrusion cooking: a review. Food Additives and Contamination, 22: 150-157.

Carvalho C.W.P., Takeiti C.Y., Onwulata C.I., Pordesimo L.O., (2010). Relative effect of particle size on the physical properties of corn meal extrudates: effect of particle size on the extrusion of corn meal. J. Food Engineering. 98: 103-109.

Frederic Robina, Heike P. Schuchmannb and Stefan 
Palzerc, (2012) Dietary fiber in extruded cereals: Limitations and Opportunities, Trends in Food Science \& Technology, 28: 23-32.

Ilo S., and Berghofer E. (1999). Kinetics of colour changes during extrusion cooking of maize grits. Journal of Food Engineering, 39: 73-80.

Mariotti A C., Pagani M.A., Lucisano M., (2006). Effect of puffing on ultrastructure and physical characteristics of cereal grains and flours. Journal of Cereal Science, 43:47-56.

Martinez L., Koundry K.P., Harper J.M., (1988). A general model for expansion of extruded products. Journal Food Science. 53: 609-615.

Obatolu V.A. \& Cole A.H. (2000). Functional property of complementary blends of soybean and cowpea with malted or unmalted maize. Food Chemistry, 70: 147-153.

Onwulata, C.I., Mulvaney, S.J., Hsieh, F., (1994). System-analysis as the basis for control of density of extruded Corn meal. Food Control, 5 (1): 39-48.

Rangana S. (2000). Handbook of Analysis and Quality Control for fruits and vegetable products, $2^{\text {nd }}$ edition, Tata McGraw-Hill Publishing Co. Ltd, New Delhi.

Rhee S.J., Chob S.Y., D.S Kimb Chaa., H.J Park., (2007)."A research note". A comparative study of analytical methods for alkali-soluble $\beta$-glucan in medicinal mushroom, Chaga (Inonotus obliquus). LWT, 41:545-549.

Sikora, P., Tosh, S.M., Brummer, Y., Olsson, O. (2013). Identification of high $\beta$-glucan oat lines and localization and chemical characterization of their seed kernel $\beta$-glucans. Food Chemistry, 137, 8391.

Udachan, Iranna S., 1Sahoo A.K. and 2 Hend G.M. (2012). Extraction and characterization of sorghum (Sorghum bicolor L. Moench) starch. International Food Research Journal, 19(1), 315-319. 